\title{
IMPACT OF OBESITY AND SURGICAL SKILLS IN LAPAROSCOPIC TOTALLY EXTRAPERITONEAL HERNIOPLASTY
}

\author{
Impacto da obesidade e habilidades cirúrgicas na hernioplastia laparoscópica totalmente extraperitoneal
}

Juliana Mika KATO', Leandro Ryuchi IUAMOTO', Fábio Yuji SUGUITA'1, Felipe Futema ESSU', Alberto MEYER ${ }^{2,3}$, Wellington ANDRAUS ${ }^{2}$

\begin{abstract}
From the ${ }^{1}$ Faculdade de Medicina da Universidade de São Paulo, ${ }^{2}$ Serviço de Transplante e Cirurgia do Fígado e Órgãos do Aparelho Digestivo, Departamento de Gastroenterologia, Faculdade de Medicina da Universidade de São Paulo; ${ }^{3}$ Centro de Reparo da Parede Abdominal, Hospital Samaritano ('University of São Paulo Medical School; ${ }^{2}$ Liver and Gastrointestinal Transplant Division, Department of Gastroenterology, University of São Paulo Medical School; ${ }^{3}$ Abdominal Wall Repair Center, Samaritano Hospital), São Paulo, SP, Brazil.
\end{abstract}

HEADINGS - Hernia. Body mass index. Herniorraphy. Laparoscopic surgery.
ABSTRACT - Background: Laparoscopic totally extraperitoneal (TEP) hernia repair is a technically demanding procedure. Recent studies have identified $\mathrm{BMI}$ as an independent factor for technical difficulty in the learning period. Aim: To analyze the effect of overweight and obesity on the technical difficulties of TEP. Method: Prospective study on patients who underwent a symptomatic inguinal hernia by means of the TEP technique. Were analyzed gender, BMI, previous surgery, hernia type, operative time and complications. Technical difficulty was defined by operative time, major complications and recurrence. Patients were classified into four groups: 1) underweight, if less than $18,5 \mathrm{~kg} / \mathrm{m}^{2} ; 2$ ) normal range if BMI between 18,5 and 24,9 $\mathrm{kg} / \mathrm{m}^{2}$; 3) overweight if BMI between $25-29,9 \mathrm{~kg} / \mathrm{m}^{2}$; and 4) obese if $\mathrm{BMI} \geq 30 \mathrm{~kg} / \mathrm{m}^{2}$. Results: The cohort had a total of 190 patients, 185 men and 5 women. BMI values ranged from 16-36 $\mathrm{kg} / \mathrm{m}^{2}$ (average $26 \mathrm{~kg} / \mathrm{m}^{2}$ ). Average operating time was $55.4 \mathrm{~min}$ in bilateral hernia (15-150) and $37.8 \mathrm{~min}$ in unilateral (13-150). Time of surgery was statistically correlated with increased BMI in the first 93 patients $(p=0.049)$. Conclusion: High BMI and prolonged operative time are undoubtedly correlated. However, this relationship may be statistically significant only in the learning period. Although several clinical features can influence surgical time, upon reaching an experienced level, surgeons appear to easily handle the challenges.

\author{
Correspondence: \\ Leandro Ryuchi luamoto \\ E-mail: leandro.iuamoto@gmail.com \\ Financial source: none \\ Conflict of interest: none. \\ Received for publication:16/03/2017 \\ Accepted for publication: 06/06/2017
}

RESUMO - Racional: A hernioplastia laparoscópica totalmente extraperitoneal (TEP) é procedimento tecnicamente exigente. Estudos recentes identificaram o IMC como um fator independente para a dificuldade técnica durante o período de aprendizagem. Objetivo: Analisar o efeito do sobrepeso e da obesidade sobre as dificuldades técnicas na TEP. Método: Estudo prospectivo em pacientes submetidos à hernioplastia inguinal sintomática por meio da TEP. Foram analisados gênero, IMC, operação prévia, tipo de hérnia, tempo operatório e presença de complicações. A dificuldade técnica foi definida pelo tempo operatório, complicações maiores e recorrência. Os pacientes foram classificados em quatro grupos: 1) baixo peso, se menor que $18,5 \mathrm{~kg} / \mathrm{m}^{2}$; 2) peso normal se IMC entre 18,5 e $24,9 \mathrm{~kg} / \mathrm{m}^{2}$; 3) sobrepeso se IMC entre 25 e $29,9 \mathrm{~kg} / \mathrm{m}^{2}$; e 4) obesos se IMC $\geq 30 \mathrm{~kg} / \mathrm{m}^{2}$. Resultados: A coorte incluiu 190 pacientes, 185 homens e cinco mulheres. Os valores de IMC variaram de $16-36 \mathrm{~kg} / \mathrm{m}^{2}$ (média de $26 \mathrm{~kg} / \mathrm{m}^{2}$ ). O tempo médio de operação foi de 55,4 min nas hérnias bilaterais (15-150) e 37,8 min nas unilaterais (13-150). O tempo cirúrgico foi estatisticamente correlacionado com o aumento do IMC nos primeiros 93 pacientes $(p=0,049)$. Conclusão: IMC elevado e tempo operatório prolongado estão indubitavelmente correlacionados. No entanto, esta relação pode ser estatisticamente significativa apenas no período de aprendizagem. Embora várias características clínicas possam influenciar o tempo cirúrgico, ao chegar a um nível experiente, os cirurgiões parecem lidar facilmente com os desafios. massa corpórea. Herniorrafia Cirurgia laparoscópica

\section{INTRODUCTION}

$\mathrm{O}$ besity and overweight has been considered an increasing global problem over the last three decades. The World Health Organization estimates a total of 700 millions obese and 2.3 billion overweight adults by 2015 . Besides directly linked to several deseases including hypertension, diabetes mellitus and cardiovascular diseases ${ }^{8,36}$, higher health costs also contributes to the increased political awareness to take action against it ${ }^{14}$.

Body mass index (BMI), which is calculated by dividing weight in kilograms by height in meters squared, is the most accepted measurement of obesity. BMI lower than $18,5 \mathrm{~kg} / \mathrm{m}^{2}$ is considered underweight; between 18,5 and $24,99 \mathrm{~kg} / \mathrm{m}^{2}$ is the normal range; exceeding $30 \mathrm{~kg} / \mathrm{m}^{2}$ is defined as obese. Several studies have demonstrated the effects of high BMI on surgical procedures, postoperative complications and anesthetics risks $2,16,24,32$. A meta-analysis of Liu et al. revealed high risks of surgical site infections and pulmonary infections after gastrointestinal procedures ${ }^{17}$. Desai et al. described high rates of skin necrosis, hernia recurrence and necessity of reoperation ${ }^{6}$. Takiguchi et al. correlated obesity with high mortality ${ }^{32}$. In terms of inguinal hernia repair, authors already presented an increased risk for postoperative complications and recurrence ${ }^{3,18,23,25,28}$. 
Endoscopic approach is widely accepted technique for hernioplasties among obese ${ }^{12}$. Between laparoscopic totally extraperitoneal (TEP) and transabdominal preperitoneal (TAPP) hernia repair, the first is preferred since it avoids intraperitoneal approach ${ }^{13,21}$ and provides less postoperative pain and fast recovery ${ }^{19}$. Recent studies have suggested variants of TEP approach using 2-port, minimizing postoperative complications ${ }^{10}$. Few studies have evaluated the influence of high BMI on hernioplasties operative time. Akagi et al. presented a statistically significant correlation between BMI and technical difficulty during laparoscopic anterior resection ${ }^{1}$. However, Park et. al. demonstrated that BMI was a significant factor influencing surgical difficulty only in the learning period ${ }^{26}$. Apart from surgeon's expertise, several clinical characteristics may influence operative time.

The aim of the present study was to analyze the effect of overweight and obesity on the technical difficulty of TEP performed by a single experienced surgeon.

\section{METHODS}

After Ethics Committee approval, a prospective study of patients who underwent a symptomatic inguinal hernia by means of the TEP technique between May 2009 and May 2014 was performed. Medical records from patients operated by a single senior surgeon were analyzed in terms of previous surgery, $\mathrm{BMI}$, type of hernia, operative time and complications. Technical difficulty was defined by prolonged operative time and major complications. All patients signed an informed consent form.

Patients were classified into four groups: 1) underweight, if BMI less than $18.5 \mathrm{~kg} / \mathrm{m}^{2}$; 2) normal range, if BMI between 18.5 and $24.99 \mathrm{~kg} / \mathrm{m}^{2} ; 3$ ) overweight, if BMI between 25 and $29.99 \mathrm{~kg} / \mathrm{m}^{2}$; and 4) obese, if BMI $\geq 30 \mathrm{~kg} / \mathrm{m}^{2}$.

\section{Statistical analysis}

Variables were analyzed by Sperman's correlation. Statistically significant values were defined as $p<0.05^{9,27}$. For statistical purpose, patients were divided into three groups: A - general, B- unilateral surgery, and C - bilateral surgery. Complicated cases were excluded for correlation analysis, since they could produce bias in length of operation.

\section{RESULTS}

Among a total of 238 patients identified on the period of study, sufficient data was obtained from 190.

There were 185 men (97.4\%) and five women (2.6\%). Average age was 52 years, average BMI was 26 and average time of surgery was 44 min (Table 1). Types and percentages of hernia are shown in Table 2.

TABLE 2 - Type of hernia

\begin{tabular}{|c|c|c|}
\hline Type of hernia & $n$ & $\%$ \\
\hline Direct & 60 & 31.6 \\
\hline Indirect & 112 & 58.9 \\
\hline Femoral & 3 & 1.6 \\
\hline Spiegel & 1 & 0.5 \\
\hline Recurrent & 29 & 15.3 \\
\hline Bilateral & 80 & 42.1 \\
\hline Unilateral & 110 & 57.9 \\
\hline
\end{tabular}

Average operative time was 55.4 min per bilateral hernia (15-150) and 37.8 min per unilateral (13-150).

Among patients with $\mathrm{BMI} \leq 24.99 \mathrm{~kg} / \mathrm{m}^{2}, 36$ had bilateral hernia; 25 at least one previous surgery; and four postoperative complications, including two conversion to open surgery, one haematoma, one cord edema and one hernia recurrence. Average operative time in this group was $41.6 \mathrm{~min}$ (16-120). Overweight patients presented 35 bilateral hernias; 32 had previous surgery; and six had complications: three conversions, one haematoma, one hematuria and one seroma. Average operative time was $43.8 \mathrm{~min}$ (13-150). Among 22 obese, nine had bilateral hernia; 10 underwent a previous surgery; and no complications were seen. Average time of surgery was $51.9 \min (20-130)$.

Distribution according to $\mathrm{BMI}$ is shown in Figure 1.

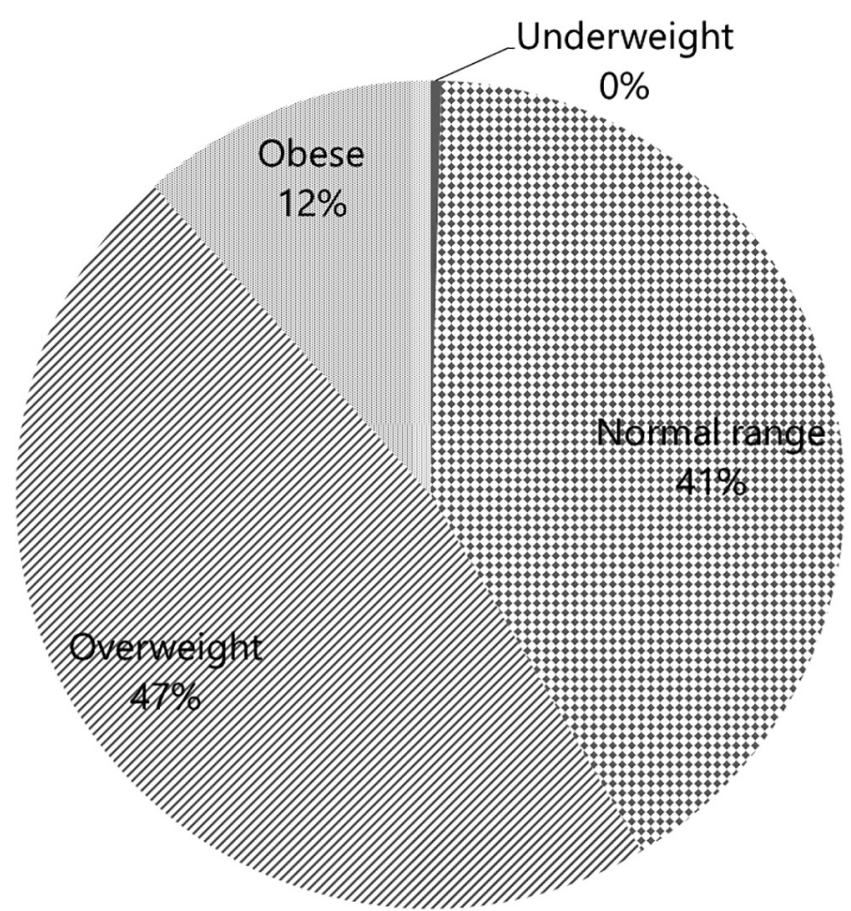

FIGURE 1 - Groups according to patient's BMI

According to ASA classification, $40 \%$ were classified as ASA $1,55.8 \%$ as ASA 2 and $4.2 \%$ as ASA 3. Four patients (2.1\%) stayed longer than $12 \mathrm{~h}$ in hospital.

In group A, time of surgery was statistically correlated with increased BMI in the first 93 patients $(p=0.049)$. Among patients who underwent unilateral hernioplasty (group B) $p$ value was 0.42 . Best $p$ value was obtained from the first 14 patients $(p=0.083)$. Patients who underwent bilateral surgery (Group $C$ ) had the best $p$-value obtained from the first 42 patients $(p<0.001$, Table 3$)$.

TABLE 3 - Correlation between operative time and hernioplasties

\begin{tabular}{|c|c|c|c|c|}
\hline & $\mathbf{n}$ & $\mathbf{p}$ & $\begin{array}{c}\text { Best } \mathbf{p} \\
\text { value }\end{array}$ & $\begin{array}{c}\mathrm{n} \text { of first patients for } \\
\text { best } \mathbf{p} \text { value }\end{array}$ \\
\hline General (group A) & 190 & 0.14 & 0.049 & 93 \\
\hline Unilateral (group B) & 103 & 0.42 & 0.083 & 14 \\
\hline Bilateral (group C) & 77 & 0.07 & $<0.001$ & 42 \\
\hline
\end{tabular}

TABLE 1 - Descriptive analysis of age, body mass index and operative time

\begin{tabular}{|c|c|c|c|c|c|c|c|c|}
\hline & $n$ & Mean value & Median value & Standard deviation & Range & 1st quartile & 3rd quartile \\
\hline Age & 190 & 52.31 & 52.00 & 14.85 & $10-85$ & 42.00 \\
\hline BMI* $^{*}$ & 190 & 25.83 & 25.00 & 3.34 & $16-36$ & 23.00 \\
\hline Operative time & 190 & 44.02 & 40.00 & 21.54 & $13-150$ & 30.00 \\
\hline
\end{tabular}

* $\mathrm{BMI}=$ body mass index 
Among this cohort of 190 patients, BMl values ranged from $16-36 \mathrm{~kg} / \mathrm{m}^{2}$ (average $25.8 \mathrm{~kg} / \mathrm{m}^{2}$ ) and there was a prevalence of men (97\%), similar to other hernia studies ${ }^{28,29}$. Mean time of surgery (44 $\mathrm{min}$ ) is also in accordance with other authors.

This series demonstrates a significant correlation between $\mathrm{BMI}$ and operative time, suggesting that higher $\mathrm{BMI}$ is related to more technical difficulty. Not only anatomical factors, but also the higher prevalence of obesity-related comorbidity (hypertension, diabetes, dyslipidemia) can make surgical procedures in obese patients more difficult. Akagi et al. presented a statistically significant correlation between BMI and technical difficulty during laparoscopic anterior resection ${ }^{1}$. It occurs mainly due to: 1) uncontrolled bleeding, since there is a release of angiogenesis-related growth factors by adipose-derived stem cells, which expands the capillary network ${ }^{7,33 ;}$ 2) abundant fat tissue, demanding more time to dissect; 3 ) diagnosis of inguinal hernia in obese can be delayed as the surrounding abdominal fat may hide the problem, therefore it can produce irritation of the hernia sac and lead to more complicated inguinal hernia ${ }^{35}$. In the series of cases operated by TEP, overweight was associated with longer operative time, being statistical significant ${ }^{30}$.

Nevertheless, the correlation was statistically significant only in the first 14 patients who underwent a unilateral hernia $(p=0,083)$ and in the first 42 patients who underwent a bilateral hernia repair $(p<0,001)$. It suggests an influence of a learning curve on technical procedure. Due to unfamiliar pelvic anatomy and limited working space, TEP hernioplasty requires time to achieve excellence. This gap is more affected by patients' clinical characteristics and anatomical aspects. Previous studies have affirmed that BMI may be a significant factor influencing surgical difficulty only in the learning period ${ }^{15,26}$. Estimated number of surgeries ranges from $30-60$ in literature $4,15,26$. Arriving at an experienced level, it seems that surgeons can deal with challenges proficiently.

Comparing bilateral and unilateral hernias, the first obviously demands longer operative time and has worse postoperative complication according to Jacob et. al. ${ }^{11}$. This probably explains the positive correlation between operative time. Studies have demonstrated preference of laparoscopic methods over open techniques, mainly due to the possibility to reach the contralateral side through the same incision ${ }^{5,20,22,34}$. Among laparoscopic approach, the prospective randomized trial of 60 patients of Sharma et. al. showed similar outcomes between TEP and TAPP for bilateral inguinal hernias ${ }^{31}$.

Difficulty associated with BMl in the learning period can help young surgeons to select hernia patients in order to overcome the learning period easily. Since this study included a series of cases of a single surgeon, further studies gathering young surgeons could be helpful to better evaluate the correlation between high $\mathrm{BMI}$ and operative time.

\section{CONCLUSION}

High BMI and longer operative time are undoubtedly related. However, this correlation may be statistical significant only in the learning period. Although several clinical characteristics may influence operative time, when arriving at an experienced level surgeons seem to deal with challenges easily.

\section{ACKNOWLEDGEMENTS}

The authors thank Mr. João Italo Dias França for his assistance with the statistics of this project.
1. Akagi $T$, Inomata $M$, Etoh $T$, Moriyama $H$, Yasuda $K$, Shiraishi $N$, et al. Multivariate evaluation of the technical difficulties in performing laparoscopic anterior resection for rectal cancer. Surg Laparosc Endosc Percutan Tech 2012;22:52-7.

2. Biccas BN, Lemme EMO, Abrahão Jr LJ, Aguero GC, Alvariz A, Schechter RB. Higher prevalence of obesity in erosive gastroesophageal reflux disease. Arq Gastroenterol; 46(1): 15-19, Jan-Mar. 2009.

3. Bosi HR, Guimarães JR, Cavazzola LT. ROBOTIC ASSISTED SINGLE SITE FOR BILATERAL INGUINAL HERNIA REPAIR. ABCD, arq. bras. cir. dig., June 2016, vol.29, no.2, p.109-111. ISSN 0102-6720

4. ChoiYY,KimZ,HurKY.Learning curveforlaparoscopictotallyextraperitoneal repair of inguinal hernia. Canadian Journal of Surgery. 2012;55(1):33-36. doi:10.1503/cjs.019610.

5. Dakkuri RA, Ludwig DJ, Traverso LW. Should bilateral inguinal hernias be repaired during one operation? Am J Surg. 2002 May; 183(5):554-7.

6. Desai KA, Razavi SA, Hart AM, Thompson PW, Losken A. The Effect of BMI on Outcomes Following Complex Abdominal Wall Reconstructions. Ann Plast Surg. 2016 Jan 21.

7. GealekmanO,BurkartA, ChouinardM,NicoloroSM,StraubhaarJ,Corvera $\mathrm{S}$. Enhanced angiogenesis in obesity and in response to PPARgamma activators through adipocyte VEGF and ANGPTL4 production. Am J Physiol Endocrinol Metab. 2008 Nov;295(5):E1056-64.

8. Heianza Y, Kato K, Kodama S, Ohara N, Suzuki A, Tanaka S et al. Risk of the development of Type 2 diabetes in relation to overall obesity, abdominal obesity and the clustering of metabolic abnormalities in Japanese individuals: does metabolically healthy overweight really exist? The Niigata Wellness Study. Diabet Med. 2014 Nov 29.

9. Hollander M, Wolfe Douglas A. Nonparametric Statistical Methods. New York: John Wiley \& Sons. (1973)

10. luamotoLR, KatoJM, MeyerA, BlancP.Laparoscopictotallyextraperitoneal (TEP) hernioplasty using two trocars: anatomical landmarks and surgical technique. ABCD, arq. bras. cir. dig. [online]. 2015, vol.28, n.2 [cited 2015-09-29], pp. 121-123

11. Jacob DA, Hackl JA, Bittner R, KraftB, Köckerling F. Perioperative outcome of unilateral versus bilateral inguinal hernia repairs in TAPP technique: analysis of 15,176 cases from the Herniamed Registry. Surg Endosc. 2015 Dec;29(12):3733-40.

12. Jenkins ED, Yom VH, Melman L, Pierce RA, Schuessler RB, Frisella MM et al. Clinical predictors of operative complexity in laparoscopic ventral hernia repair: a prospective study. Surg Endosc. 2010 Aug:24(8):1872-7.

13. Kassir R, Tiffet O, Bourbon M, Meyer A, Gugenheim J, Debs T et al. Laparoscopic Hernia Repair With 3-Millimeter Instruments: A Point of Technique and Illustrative Case Video. Surg Innov. 2015 Aug;22(4):366-7.

14. Lette M, Bemelmans WJ, Breda J, Slobbe LC, Dias J, Boshuizen HC. Health care costs attributable to overweight calculated in a standardized way for three European countries. Eur J Health Econ. 2014 Nov 29.

15. Lim JW, Lee JY, Lee SE, Moon JI, Ra YM, Choi IS et al. The learning curve forlaparoscopictotallyextraperitoneal herniorrhaphybymovingaverage. J Korean Surg Soc. 2012;83:92-96.

16. LindauerB,SteurerMP,MüllerMK, DullenkopfA.Anestheticmanagement of patients undergoing bariatric surgery: two year experience in a single institution in Switzerland. BMC Anesthesiol. 2014 Dec 18;14:125.

17. Liu Y, Dong Y, Wu X, Chen H, Wang S. Influence of high body mass index on mortality and infectious outcomes in patients who underwent open gastrointestinal surgery:Ameta-analysis. Am J InfectControl.2016Jan29.

18. Meyer A, Berger E, Monteiro Jr O, Alonso PA, Stavale JN, Gonçalves MPS. Quantitative and qualitative analysis of collagen types in the fascia transversalis ofinguinal hernia patients. Arq. Gastroenterol.[online].2007, vol.44, n.3 [cited 2017-01-24], pp.230-234. Available from: <http://www. scielo.br/scielo.php?script=sci_arttext\&upid=S0004-28032007000300010\&ln $\mathrm{g}=$ en\&nrm=iso>. ISSN 0004-2803.

19. Meyer A, Blanc P, Kassir R, Atger J. Laparoscopic Hernia: UmbilicalPubis Length Versus Technical Difficulty. JSLS : Journal of the Society of Laparoendoscopic Surgeons. 2014;18(3):e2014.00078. doi:10.4293/ JSLS.2014.00078.

20. Meyer A, Bonnet L, Bourbon M, Blanc P. Totally extraperitoneal (TEP) endoscopic inguinal hernia repair with TAP (transversus abdominis plane) block as a day-case: a prospective cohort study. J Visc Surg. 2015 Jun;152(3):155-9.

21. Meyer A, Dulucq JL, Mahajna A. Laparoscopic totally extraperitoneal hernioplasty with nonfixation of three-dimensional mesh: Dulucq's technique. Arq Bras Cir Dig. 2013 Jan-Mar;26(1):59-61.

22. Mihăileanu F, Chiorescu S, Grad O, Negrea V, Silaghi H, Mironiuc A. The Surgical Treatment of Inguinal Hernia Using the Laparoscopic Totally Extra-Peritoneal (TEP) Technique. Clujul Med. 2015;88(1):58-64.

23. Módena SF et al. Influence of tobacco, alcohol and diabetes on the collagen of cremaster muscle in patients with inguinal hernias. $A B C D$, arq. bras. cir. dig., Dec 2016, vol.29, no.4, p.218-222. ISSN 0102-6720 
24. Nelson JA, Fischer JP, Cleveland EC, Wink JD, Serletti JM, Kovach SJ 3rd. Abdominal wall reconstruction in the obese: an assessment of complications from the National Surgical Quality Improvement Program datasets. Am J Surg. 2014 Apr;207(4):467-75.

25. Palermo $\mathrm{M}$ et al. Hernioplasty with and without mesh: analysis of the immediate complications in a randomized controlled clinical trial. $A B C D$, arq. bras. cir. dig., Sept 2015, vol.28, no.3, p.157-160. ISSN 0102-6720

26. Park BS, Ryu DY, Son GM, Cho YH. Factors influencing on difficulty with laparoscopic total extraperitoneal repair according to learning period. Ann Surg Treat Res. 2014 Oct; 87(4): 203-208.

27. Pereira, JCR. Bioestatística em Outras Palavras. 1 ed. EDUSP-SP, 2010.

28. Rosemar A, Angeras U, Rosengren A. Body mass index and groin hernia: a 34-yearfollow-upstudyinSwedishmen.AnnSurg.2008;247:1064-1068.

29. Rosemar A, Angerås U, Rosengren A, Nordin P. Effect of body mass index on groin hernia surgery. Ann Surg. 2010 Aug;252(2):397-401.

30. Schouten N, Elshof JW, Simmermacher RK, van Dalen T, de Meer SG CleversGJetal.Selecting patientsduring the "learning curve" ofendoscopic Totally Extraperitoneal (TEP) hernia repair. Hernia 2013;17:737-43.

31. Sharma D, Yadav K, Hazrah P, Borgharia S, Lal R, Thomas S. Prospective randomized trial comparing laparoscopic transabdominal preperitoneal (TAPP) and laparoscopic totally extra peritoneal (TEP) approach for bilateral inguinal hernias. Int J Surg. 2015 Oct;22:110-7.
32. Takiguchi M, Yoshihisa A, Miura S, Shimizu T, Nakamura Y, Yamauchi H et al. Impact of body mass index on mortality in heart failure patients. Eur J Clin Invest. 2014 Dec;44(12):1197-205.

33. Volz AC, Huber B, Kluger PJ. Adipose-derived stem cell differentiation as a basic tool for vascularized adipose tissue engineering. Differentiation. 2016 Mar 11.

34. Wauschkuhn CA, Schwarz J, Boekeler U, Bittner R. Laparoscopic inguinal hernia repair:gold standard in bilateral hernia repair? Results ofmorethan 2800 patients in comparison to literature. Surg Endosc 2010;24:3026-30.

35. Zendejas B, Hernandez-Irizarry R, Ramirez T, Lohse CM, Grossardt BR, Farley DR. Relationship between body mass index and the incidence of inguinal hernia repairs: a population-based study in Olmsted County, MN. Hernia. 2014 Apr;18(2):283-8.

36. Zhang L, Zhang WH, Zhang L, Wang PY. Prevalence of overweight/ obesity and its associations with hypertension, diabetes, dyslipidemia, and metabolic syndrome: a survey in the suburban area of Beijing, 2007. Obes Facts. 2011;4(4):284-9. 